\title{
Use of Social Media for Informal Language Learning by Malaysian University Students
}

\author{
AFENDI HAMAT \\ Faculty of Social Sciences and Humanities, \\ Universiti Kebangsaan Malaysia \\ fendi@ukm.edu.my \\ HASLINDA ABU HASSAN \\ Faculty of Education, \\ Universiti Kebangsaan Malaysia
}

\begin{abstract}
Social networking services (SNSS) are a much-touted technology for improved learning, yet very little research goes beyond the classroom-level controlled application of SNSs. This paper provides a look at reported usage and application of SNSs beyond the classroom, where data is scarce. The paper describes an investigation on whether Malaysian university students think SNSs are helpful for learning English, and the areas of language proficiency that these students perceived to benefit the most from their usage of SNSs. A total of 6,085 students participated in the online survey. Results indicate that an overwhelming majority (99.7\%) make use of SNSs to learn English outside the classroom and 97.4\% of these believe their use of SNSs helps improve their proficiency. The respondents indicated that the areas of proficiency that benefitted the most from their use of SNSs are writing, communication, vocabulary development and reading. In contrast, grammar as well as listening and speaking benefitted the least. The results presented a much needed, and currently lacking, view into the actual utility and use of SNSs for the purpose of informal learning of English among students in Malaysian universities.
\end{abstract}

Keywords: informal language learning; social media; language skills; language acquisition

\section{INTRODUCTION}

The popularity and pervasiveness of social media or social networking services (SNSs) such as Facebook and Twitter among young adults have attracted the interest of educators. Arguably, the major attraction of academic use of SNSs for educators is not only the number of students who are always logged on to these sites. The innate design of these sites facilitates personalization, communication, collaboration and sharing (McLoughlin \& Lee 2008; Subrahmanyam, Reich, Waechter, \& Espinoza, 2008) which aligns well with many of the current approaches to teaching and learning. Indeed, research suggests that the use of SNSs for academic related purposes encourages participation that fulfils the functions of social learning (Greenhow \& Robelia 2009; Chen \& Bryer 2012) and social constructivist approach to learning (Romero-Frías \& Arquero 2013). Using SNSs for education related activities creates opportunities for students not only to socialize (Madge, Meek, Wellens \& Hooley 2009; Selwyn 2009) but also to share experiences and learn from each other.

Additionally, SNSs have provided students a tool that helps them to fluidly transition between online and face-to-face contacts (Knight \& Rochon 2012; Ellison, Steinfel \& Lempe 2007), helping them to collaborate, support and learn from each other (Saykili \& Kumptepe 2014) while making it easier for them to be engaged in their learning and adjust to university life in general (Selwyn 2009). In fact, the increasing number of reviews of literature in relation to SNSs in education in the past few years (Aydin 2012; Gao, Luo \& Zhang 2012; Hew 2011; 
Manca \& Ranieri 2013; Manca \& Ranieri 2016; Rodríguez-Hoyos, Haya Salmón \& FernándezDíaz 2015; Yang, Wang, Woo \& Quek 2011; Tess 2013) attests and highlights the interest of educators and instructors, particularly in the higher education setting, towards the use of SNS as a learning and teaching tool, especially popular SNSs like Facebook where uptake is high globally among university-going users.

Similarly, the potential of SNS use for education has also attracted the interest of language researchers and practitioners who are either eager to explore the potentials promised by these technologies and their benefits for language learning (Saykili \& Kumptepe 2014) or because of their mass appeal to the present generation of learners (Zourou 2012). The same interest too can be seen among language educators and researchers in Malaysia as the number of research on SNSs especially Facebook and its use for language learning is on the rise (e.g. Kabilan, Ahmad \& Abidin 2010; Looi \& Yusop 2011; Yunus, Salehi \& Chenzi 2012; Yunus \& Salehi 2012; Mahmud \& Ching 2012; Kasuma 2017).

Findings from research on SNS use for language learning reveal that it promises a lot of benefits. Similar to findings on educational use of SNSs where ease of use, familiarity, convenience and flexibility offered by these services were often cited for students' use of SNSs for learning (Mazman \& Usluel 2010; Tan \& Low 2010; Balakrishnan, Teoh, Pourshafie \& Liew 2017), language learners too valued these affordances (Lamy \& Zourou 2013; McBride 2009). They also felt that SNSs like Facebook are easier to use in comparison to their university's own LMS, particularly when accessing content via mobile platforms (Gamble \& Wilkins 2014). Research shows that use of SNSs in language learning is conducive to the promotion and improvement of language skills (McBride 2009; Godwin-Jones 2006) and in enhancing the learning process (Dogoriti \& Pange 2013).

Most of the research described so far has been instructor-led use of SNSs for language education. However, it has been argued that 1) it is the affordability of the technology and students' familiarity with and usefulness of SNSs for learning in terms of convenience and flexibility, and 2) SNSs' accessibility and availability as well as their networking capabilities which are the factors that have encouraged students to use SNSs for informal learning among themselves (Vivian 2011; Mazman \& Usluel 2010, Lay Shi, Thang \& Mohd Noor, 2018). Trinder (2017, p. 402) for instance argued that "the ready availability of new technologies" create "opportunities for the incidental as well as the deliberate practice of English" which has "multiplied and far exceed(ed) what can be done in more formal environments". Indeed, SNSs like Facebook can be used for educational purposes but mainly to serve as informal learning environments and as supplemental tools for formal learning (Dabbagh \& Kitsantas, 2012).

However, research on SNS use for language learning seems to be largely instructor-led or used in conjunction with instruction in the language classroom, particularly in the context of Malaysia. Trinder (2017) commented along the same line, mentioning that few studies have examined how students view the increased exposure to the English language via digital resources in relation to learning potential. This, therefore, raises the question of whether Malaysian students do actually use their SNSs for any informal language learning activities and whether they perceive these as contributing to their proficiency in the language.

This paper presents the results of a study to address the gap mentioned in the previous paragraph. Specifically, the study dealt with the following research questions: 
1. Do students in Malaysian institutions of higher learning perceive use of SNSs as helpful in improving their English language proficiency?

2. In which areas of English language proficiency do the students think of SNSs as most helpful in improving their English language proficiency?

\section{REVIEW OF LITERATURE}

The communal and social nature of SNSs lends itself to the formations of discourse communities. The concept of discourse community is described as groups that have goals or purposes and use communication to achieve those goals (Swales, cited in Borg 2003). Borg (2003, p. 398) went on to explain that membership in a discourse community is typically "a matter of choice" where members often "actively share goals and communicate with other members to pursue those goals". Gunawardena et al. (2009, p. 10) described discourse as "socially accepted association among ways of using language, other symbolic expressions, and 'artefacts' of thinking, feeling, believing, valuing, and acting that can be used to identify oneself as a member of a socially meaningful group or "social network". The idea of a discourse community existing within the same 'space' and interdependent with the communities of practice as a learning community is inseparable because in online communities of practice, the discourse or language of the community must be negotiated to establish a community of belonging in which members have mutual respect and understanding of each other. Moreover, Wenger (1998) himself explained that it is the interactions among the members which are essential in making them a community of practice. Thus, in looking at how a group of students with shared interests use SNSs, it is the interaction and communication taking place within the community that would help sustain learning.

In an ESL context like Malaysia, arguably communication and interaction in these online spaces would entail some level of English being used, particularly when the learning community is set up for the purpose of supporting academic endeavours at university as evidenced by the findings of Maryam Jazayeri Gharehbagh, Siti Hamin Stapa and Saadiyah Darus (2019) as well as Azura Omar, Zaini Amir and Maslawati Mohamad (2018). Moreover, Espinosa (2015), citing Crystal (2011) and Seedhouse (2004) elucidated that English is now the predominant language of online communication among youngsters as a result of globalisation of digital media despite the language not being their mother tongue. The English being used might not be 'perfect', but it may implicitly contribute towards the improvement of the students/members' language proficiency and skills. Furthermore, the online environment of SNSs can provide opportunities for engagement with authentic materials, activities and language use, enabling the students within the learning community exposure to real language, and through the shared discourse, negotiate and construct meaningful communication (Woo, Herrington, Agostinho \& Reeves 2007).

Research has also pointed out the value of SNSs in informal learning. The literature seems to suggest that students commonly and naturally use SNSs as an informal academic tool to work with their peers or to organise class projects or exchange information about coursework (Bosch 2009; Madge et al. 2009; Selwyn 2009). This has led Kiser and Porter (2011) to question whether SNS use for educational purposes serves a legitimate reason or if it disengages the learners from the educators, mainly because of the 'social' value of such sites as perceived by 
many learners (Mazer, Murphy \& Simonds 2007) despite these sites having the capability or features that make them educationally useful and relevant.

Students use SNSs to communicate with each other more than they do with their teachers (Salaway, Caruso \& Nelson 2008; Smith, Salaway \& Caruso 2010). This clearly supports the findings that much of SNS use for education related activities is to support the informal learning practices (Ellison 2008; Selwyn 2007) of peer to peer communication and collaboration among classmates or course-mates, and not much on formal learning involving student and faculty interaction (Smith et al. 2010). Thus, this leads to the concern among academics and scholars if students are really open to the idea of having faculty on their SNSs. Hewitt and Forte (2006) for instance, in their research that investigated into students' perceptions of faculty having Facebook presence discovered that while students find faculty presence on Facebook acceptable, it was only considered so for purposes of social and interpersonal communication or for getting to know their lecturers better, and not for educational purposes. In fact, their study found that one third of the students they sampled did not believe in faculty being present on Facebook at all.

Madge et al. (2009) conducted research using an online survey among first year students $(n=213)$ of a British university focusing on Facebook. The findings showed that Facebook is mainly used as a 'social glue' that helped these students to settle into their university life and the students mainly thought of Facebook's use for social reasons and not for formal teaching purposes even though the students did sometimes use it for informal learning purposes such as the micro management of their life as a student in university. This finding is similar to the study by Daalsgard (2006) who found that students were using SNSs as a form to facilitate 'transparency' between students, a way in which they get insights into each other's work, ideas and creations. Additionally, the 2008 ECAR study discovered that the students were more interested in peer-to-peer interaction for both social and academic purposes in comparison to peer-to-tutor interaction (Salaway et al. 2008), highlighting the concept of a "personal online space".

In their online survey of SNS use among undergraduates taking one or more business class at a university ( $\mathrm{n}=227)$, Kiser and Porter (2011) discovered that female students spent more time on Facebook, where these activities involved posting photographs, updating their profiles and seeking employment information more than their male counterparts. When enquired on whether their university professors used SNSs as part of their teaching, $89 \%$ answered that none of them had used SNS in their courses. Nevertheless, the students (almost 74\%) mentioned that Facebook can be used by their professors for coursework to enhance their educational experience in terms of communicating assignments, providing details of the course, using it as a teaching tool, teaching students how to be professional in their own use of SNSs and connecting with students using a technology which is already familiar to the students. A key use of SNSs in education as perceived by these students seems to stem around the notion of 'communication'. Around $26 \%$ of the students who felt that their professors should not use SNS for teaching mentioned reasons of ineffectiveness of SNSs for educational purposes, the need for the sites to remain 'social' in their usage, and the lack of privacy for the students.

Ophus and Abbitt (2009) investigated the extent to which students are using SNSs for personal communication and activities related to their academic course work and the students' perceived value of integrating SNSs with their university courses. Their sample involved 110 students at a comprehensive Midwestern university in the United States with the majority being female students (107) and between the ages of eighteen and nineteen (100). They discovered that the majority of students indicated using Facebook daily or multiple times daily, but very few 
reported using SNSs for academic purposes. The most common type of communication activity involved communication with friends, followed by family members. A large majority indicated never using Facebook to communicate with instructors, but most have used Facebook to communicate with their peers. In terms of the course related activities, the highest ratings were for using SNSs to access course notes and other materials, viewing course schedules, communicating with other students in their course and joining a SNS group for students in their course. Sixty-six students perceived that when SNSs are used as an academic tool, the greatest benefit would come from the increased communication among the students in the course, followed by convenience (25 students). Nevertheless, the students' major concerns were distractions (57 students) and privacy should SNSs be used as an academic tool. The students express worry at the possibility of their instructors seeing their profiles and other information intended for a more private audience such as families and close friends.

Towner and Munoz (2011) conducted an online survey among students $(n=283)$ at a private university on the East Coast of the United States to examine students' attitudes toward SNSs (Facebook) as a tool for learning. The respondents were from a broad range of majors and $72 \%$ were undergraduates while the rest were postgraduates. They discovered that the students mainly used Facebook to maintain offline relationships such as connecting with old friends, classmates, or family. Interestingly, most of the students' (75\%) Facebook relationship involved connecting with their classmates where the activities involved writing on the 'walls' of their classmates, sending messages, creating events and inviting classmates to the events, publishing notes and tagging students in their class. Thus, Towner and Munoz's (2011) study indicated that students are using SNSs to connect with their peers and getting to know their classmates better. From their study, Towner and Munoz (2011) discovered that on average more than half of the students surveyed reported using Facebook chiefly for informal learning purposes 1 to 5 times per semester where they interacted with their peers about non-required course related matters. These involved matters such as finding other students in their course, getting contact information of classmates, leaving messages about class information, finding out missing information due to non-attendance to class, setting up meetings, chatting about something related to the class or course, talking about a lecture, and obtaining class notes from others. The research findings suggest a common theme that is students are more comfortable using SNSs in an informal manner.

Warschauer (2009, p. xx) in his foreword in the book "Handbook of Research on Web 2.0 and Second Language Learning" commented that technology should not be regarded as "a magic bullet to solve educational problems, but rather as a powerful tool that can have both positive and negative impact, and that must be carefully exploited". His observation rings true when many of the research on SNS use for language learning reviewed for this study revealed that use of these sites for pedagogic purposes or in the academic context brings both advantages and disadvantages to the learners.

In her study, Alm (2015) investigated the use of Facebook for out-of-class informal language learning using data involving 190 language students (143 females, 48 males) of a university in New Zealand. Alm (2015) explained that the informal use of Facebook in language learning mainly refers to learner-initiated use of the SNS for communication with others, including native speakers. She reasoned that these interactions are more difficult to track and quantify and thus have received not much attention in the literature and are less well understood. In this study, students were native speakers of English but were studying various other foreign languages offered at the language department of the university. These students were studying 
languages such as Chinese, French, Japanese, German and Spanish at the beginner, intermediate and advanced level. Data were collected via the completion of an online questionnaire that examined (1) the students' perception of Facebook as a multilingual environment, (2) their practices of writing online, and finally (3) their views of the value of their educational experience.

Findings of this study revealed that the students were using a range of Facebook features to expose themselves to the languages they were studying. For example, a small number changed the default language to the L2 language, while some reverted between English and L2. The large majority used English as the default language. Nevertheless, Alm (2015) found that the more advanced the students are in their language study, the more likely it is for them to keep the language setting to the L2 they were studying or changing the language back and forth between English and their L2. The more advanced students were also more likely to be part of a study group set up by students and to belong to special interest groups. The findings thus revealed that the use of multilingual features increased with students' proficiency where the more advanced students used a variety of features in Facebook to gain more language input, particularly to communicate with native speakers. The interactions with native speaker friends rarely occurred in public spaces and tend to take place in the private channels on Facebook, both chat and private message. These interactions also increased with proficiency and number of close native speaker friends.

In relation to views on the usefulness of Facebook for language learning, students' comments were grouped into three main categories. First, Facebook provided an informal environment where there was less pressure to produce language as compared to the language classroom; second, Facebook also provided opportunities to observe native speaker activities and their conversations, providing a space for exposure to authentic language; and third, Facebook provided opportunities to observe and participate in real conversations with native speakers, about interesting topics, using relevant language. Similar to other studies, Alm (2015) discovered that Facebook provided an alternative venue for the students to practice their L2 in an authentic and real setting, providing a more casual and intimate environment where beginner and shy students feel less shy and more confident to interact in the language they are studying.

Alm (2015) went on to explain that the findings for the first and second part of her study strongly suggested that L2 Facebook use (passive and active) is linked to language proficiency. However, the results also show that overall use, even among advanced language learners is not great. Students' rating on a 5-point scale seemed to indicate that many of the advanced L2 learners considered Facebook moderately useful for L2 exposure and practice, and even the more active ones felt that their informal language engagement was not perceived as useful in the context of formal language learning. Citing Eaton (2010), Alm (2015) commented that informal language learning has often been perceived as second-rate learning, so much so that students themselves do not value their informal language experiences as learners. Her conclusion brings attention to the need for educators to recognise the value of informal out-of-class language learning experiences of students and start encouraging such learning.

\section{DATA COLLECTION}

Data was collected through an online survey administered via the SurveyMonkey survey tool. A survey is deemed most appropriate for the research questions mentioned earlier as it is suitable 
for gathering data from a large number of subjects in order to measure their behavioural patterns (Ary, Jacobs, Razavieh, \& Sorensen, 2009). Previous studies looking at patterns of usage for SNSs also made use of the survey method (Ellison, Steinfield, \& Lampe, 2008; Roblyer, McDaniel, Webb, Herman, \& Witty, 2010; Selwyn, 2009).

A total of 6,085 students responded to the online survey. Table 1 presents their demographic background.

TABLE 1. Demographic Background

\begin{tabular}{llcc}
\hline Demographic Info & Category & Frequency (F) & Percentage (\%) \\
\hline Gender & Male & 2234 & $36.7 \%$ \\
& Female & 3851 & $63.3 \%$ \\
Age Group & Between 17 to 20 & 2186 & $35.9 \%$ \\
& Between 21 to 24 & 3117 & $51.2 \%$ \\
& Between 25 to 30 & 465 & $7.6 \%$ \\
& Between 31 to 35 & 182 & $3.0 \%$ \\
Level of Study & More than 36 years old & 135 & $2.2 \%$ \\
& Undergraduates & 5063 & $83.2 \%$ \\
& Postgraduates & 674 & $11.1 \%$ \\
Type of IHL & Others & 348 & $5.7 \%$ \\
& Public & 5869 & $96.5 \%$ \\
& Private & 216 & $3.5 \%$ \\
\hline
\end{tabular}

\section{RESULTS AND DISCUSSION}

The results showed that all the students who responded to the survey owned at least one SNS account. It was important at the outset to determine if the students were using their SNSs for English language learning as literature highlights that students use of SNSs is more for social than academic related purposes (e.g. Madge et al. 2009; Selwyn 2009). Hence, in connection to the first research question, the respondents were first asked if they do use their SNS for English language learning in the questionnaire. The result is presented in Figure 1.

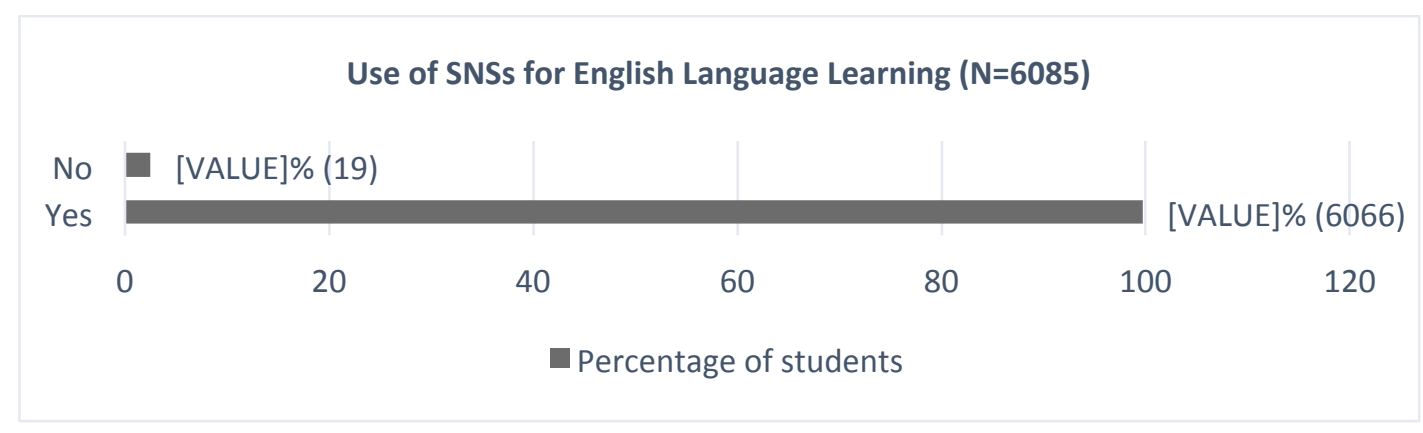

FIGURE 1. Use of SNSs for English language learning

Based on the respondents' responses as presented in Figure 1, it was found that almost all the students except for 19 respondents $(0.3 \%)$ reported using their SNSs for learning English. This was a majority of 6066 respondents $(99.7 \%)$. This shows that almost all the students in this study utilised their SNSs for English language learning. Next, they were asked on perceived usefulness of SNSs to help improve their proficiency in English. The results are presented in Figure 2 below. 
Perceived helpfulness of SNS to help improve English Language Proficiency $(\mathrm{N}=6085)$

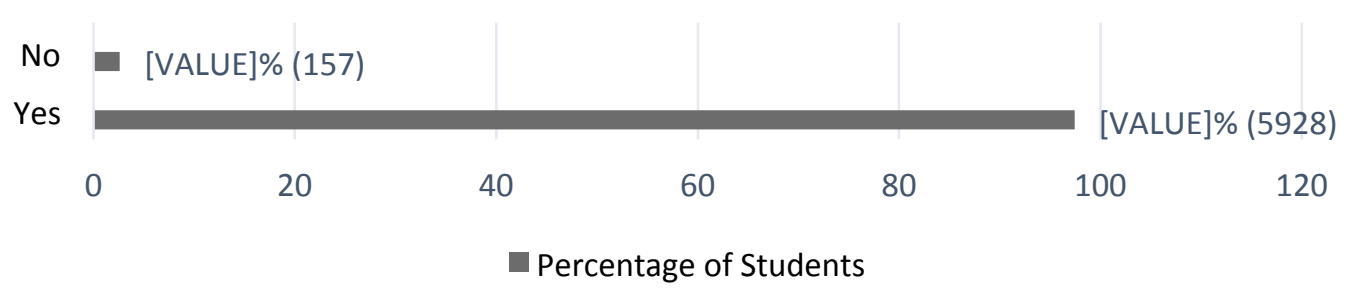

FIGURE 2. Perceived helpfulness of SNS to help improve English language proficiency

Based on Figure 2, a total of 5928 respondents (97.4\%) perceived use of SNSs as helpful in improving their English language proficiency. The remaining 157 respondents $(2.6 \%)$ responded otherwise. The large number who saw the use of SNSs as helping to improve their English proficiency is reassuring. This highlights positive attitudes among students towards the use of SNSs in improving their English language proficiency. The finding echoes many other studies on SNS use and language learning that reported positive attitudes and perception of students towards utilising SNSs for learning of languages (e.g. Kabilan et al. 2010; Mahmud \& Ching 2012; Yunus et al. 2012; Lomicka \& Lord 2016). The finding also suggests that students are appropriating technologies, in this case their social sites for the purpose of language learning and finding the use of these sites as contributing towards their proficiency in the English language.

The next question looks at the areas of English proficiency that the respondents believe to benefit the most from their use of SNSs. The questionnaire required the respondents to rate based on a 5-point Likert scale the perceived helpfulness of SNS use for improving different areas of English language skills with 1 indicating 'Not helpful at all' and 5 indicating 'Extremely helpful'. The total number of respondents who responded to this question was 5928 respondents, i.e. the same number of respondents who reported perceiving use of SNSs helpful in improving their English language proficiency. The balance of 157 respondents who did not perceive use of SNSs as helpful was directed to other parts of the questionnaire and were therefore excluded from the analysis. Table 2 presents the mean, mode and standard deviation (SD) for each of the areas of English language skills in which students perceived use of SNSs helpful, with the mean scores presented in descending order.

TABLE 2. Mean, mode, and standard deviation (SD) for areas of English language skills in which SNS use is perceived as helpful $(\mathrm{N}=5928)$

\begin{tabular}{lccc}
\hline Areas of English language skills & Mean & SD & Mode \\
\hline Writing Skills & 4.08 & 0.86 & 4.0 \\
Communication Skills & 3.74 & 1.03 & 4.0 \\
Vocabulary & 3.61 & 0.95 & 4.0 \\
Reading Skills & 3.27 & 1.14 & 4.0 \\
Grammar & 2.81 & 1.19 & 2.0 \\
Listening and Speaking Skills & 2.32 & 1.22 & 1.0 \\
\hline
\end{tabular}

Overall, the result in Table 2 shows four areas of English language skills with mean scores above 3.0, namely writing, communication, vocabulary and reading. These four areas also attained mode of 4.0, indicating many respondents perceive use of SNSs 'Very helpful' in 
improving their proficiency in these four areas. In contrast, grammar and listening and speaking skills obtained mode of 2.0 ('Slightly helpful') and 1.0, ('Not helpful at all') respectively, and both skills scored mean values below 3.0. The area of English language skills in which use of SNSs is perceived most helpful by the respondents is writing skills with mean score of 4.08 (SD 0.86). This is followed by communication skills with mean score of 3.74 (SD 1.03), vocabulary with mean score of 3.61 (SD 0.95) and reading skills with mean score of 3.27 (SD 1.14). Nevertheless, among these four areas of English language skills, only writing and vocabulary attained slightly lower SD values (below 1.0). Lower SD value indicates that the individual scores were closer to the mean value, reflecting less variation or more homogeneity in individual responses.

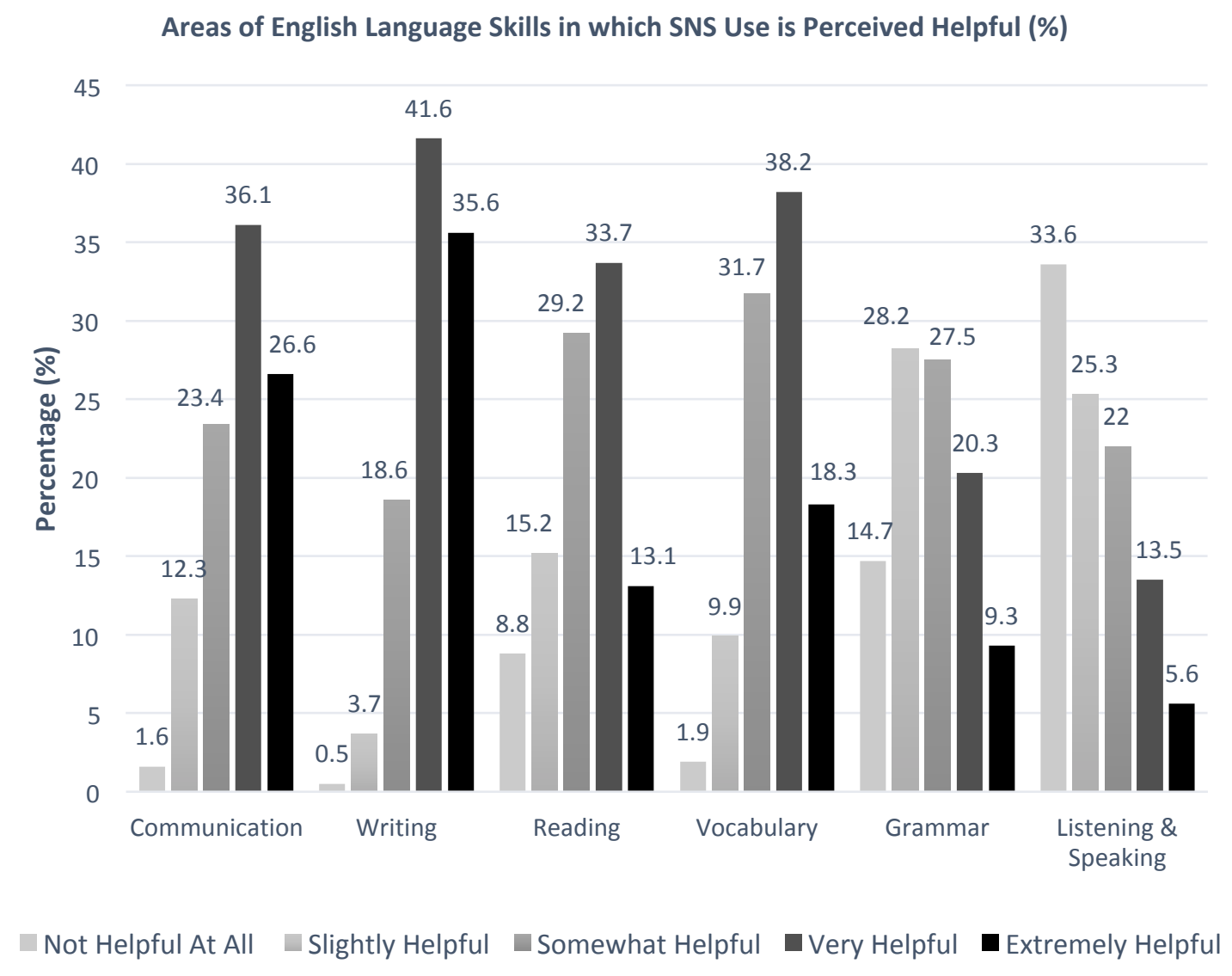

FIGURE 3. Areas of English language skills in which SNS use is perceived helpful

As can be observed in Figure 3, the vast majority of respondents selected 'Very helpful' for four out of the six areas of English language skills. They indicated perceiving use of SNS very helpful in developing their communication skills (35.2\%), writing skills (40.5\%), and reading skills (32.8\%), and in expanding their English language vocabulary (37.3\%). Results in Figure 3 disclose that even though writing, communication, reading and vocabulary attained mean score above 3.0 (see Table 2), the pattern in the students' response distribution is dissimilar. 
For two of these four language skill areas, namely developing communication and writing skills, the trend in the distribution of responses was similar with many gravitating mainly towards the higher end of the scale i.e. 'Very helpful' and 'Extremely helpful'. This suggests that students perceive SNS use very favourably in relation to improving their communication and writing skills in English. As discussed earlier, this is reflective of how communication or interaction happens in these online spaces where communication is mainly carried out in written form mode. However, for developing reading skills and expanding vocabulary, the pattern in response distribution gravitated heavily towards the middle where the majority of responses fall into the category of 'very helpful' and 'somewhat helpful'. Nonetheless, vocabulary attained higher mean score (3.61) than reading skills (3.27). This is mainly because the number of respondents perceiving SNS use 'Extremely helpful' for vocabulary was much higher in comparison to reading skills.

In contrast, for the last two areas of English language skills, i.e. improving English language grammar and developing listening and speaking skills, the majority of responses fall in the lower end of the scale of helpfulness. More specifically, the bulk of the responses were categorised as 'Not helpful at all' (32.8\%) for listening and speaking skills, and 'Slightly helpful' (27.5\%) for improving English grammar. Nonetheless, for improving English grammar, a large portion of responses were divided between the category of 'Slightly helpful' (27.5\%) and 'Somewhat helpful' (26.8\%). To sum up, the findings in general reveal that many students perceive use of SNSs helpful in improving their English language proficiency, particularly in skills of writing, communication, vocabulary and reading. In contrast, students found use of SNSs for informal learning of English the least helpful for areas of grammar and listening and speaking skills.

The finding in this section is reflective of other studies that looked at SNS use and English language learning. Indeed, many of the other studies on SNSs and language learning have investigated how SNSs can be used in the English language classroom to support development of writing, reading, communication skills and vocabulary development (e.g. Kabilan et al. 2010; Yunus et al. 2012; Blattner \& Fiori 2009; Gamble \& Wilkins 2014). This somewhat suggests that use of SNSs are facilitative in and suitable for developing these four areas of language skills. For example, Kabilan et al. (2010) in their study found that students perceive the use of Facebook as an online language learning environment contributes towards improvements of their language skills as it facilitated practise of communication, writing, and reading skills as well as learning of new words.

Kasuma (2017) in her study found use of Facebook for English language learning contributing towards her students' language acquisition in that it helped them learn new words and vocabulary. Her students also reported feeling more confident and motivated to read and communicate in English. Similarly, findings in AbuSa'aleek's (2016) study revealed that the students perceived Facebook as facilitating, supporting, and encouraging their English language learning, hence assisting them in the process of improving their English language skills, especially in learning new vocabulary, overcoming language mistakes, and enhancing their communication and writing skills. The finding in this study is supportive of the findings in these other studies where students perceive use of SNSs helpful in improving their language skills, particularly in relation to writing, communication, vocabulary and reading skills.

The tools in SNSs support communication through a variety of channels, and communication although can be carried out in audio format is mainly carried out in the written form in these SNSs. Facebook for example makes it possible for students to communicate and 
interact both asynchronously and synchronously because of the tools embedded within the site. Indeed, SNSs can provide learners lots of opportunities to practice writing through status updates, comments, instant messages, mail messages, and blog posts. Moreover, similar to other computer mediated communication (CMC), students may feel that communicating on SNSs is more authentic and meaningful (Prichard 2013) as they would have "an audience to read their work and share their thoughts and feelings" (Kabilan et al. 2010: 184). Ekoc (2014) concurred, explaining that in most classroom writing situations, the writing can still be seen as an individual activity with mostly the teacher as the sole audience or sometimes carried out for peer checks. In contrast, SNSs allow for authentic communication as language learners are more focused on meaningful communication and not the mechanics of language learning (Shaw 2015). Moreover, the casual nature of writing and communicating in SNSs allows for creativity and is less punishing on the language mistakes that learners make.

Despite perceiving the potential of SNSs to improve their language proficiency in the four areas discussed above, the students in this study perceived use of SNSs as least helpful for improving grammar and developing their listening and speaking skills. This finding is slightly different from that of Suthiwartnarueput and Wasanasomsithi (2012) who found students enjoyed use of Facebook as a platform to discuss grammar (and writing). However, it could be argued that Suthiwartnarueput and Wasanasomsithi used Facebook as part of the formal teaching of English and thus the language instructor was available to provide instruction and facilitate content learning (grammatical rules and terms) unlike this present study which looked at students' use of SNS for informal learning of English, i.e. language learning that is student initiated and happens outside the language classroom where language instructors are not present (unless the students initiate communication with their instructors on their SNSs). Prichard (2013) also pointed out that not much research has been done on listening and speaking skills on SNSs, suggesting less interest among language researchers in the use of SNSs for developing listening and speaking skills.

It could be said that learning of grammar and listening and speaking skills would in an informal setting require a more 'conscious' effort on the part of the students, either to notice the grammar structures or the spoken utterances of the speakers of English, i.e. the mechanics of the language. This is even more so when the learning of English is independent of the language instructors, where students need to have the awareness and ability to notice the language points themselves. In this situation, the students would be co-constructing their new knowledge collaboratively while interacting with their peers, and the 'more knowledgeable others' would be peers with more advanced knowledge who would be providing the linguistic and social scaffolding to the rest. Unless these peers with more advanced knowledge are present, students might not be able to notice the grammatical form or the spoken utterances. Lomicka and Lord (2016, citing Schmidt 1990) argued that input that is comprehensible is most likely to be noticed and processed by learners. However, when the learner fails to notice or be consciously aware of the input because of a gap in their knowledge, and negotiation of meaning is not supported by others, the input would not become an intake.

Moreover, in these social sites the intention may not be primarily to learn English, but more of socialising; the language learning happens as a by-product of socialising with friends and peers. Arguably, the informal learning of English through the use of SNSs in the context of this study may be seen by students as language learning that may be combined with other goals such as entertainment, information search and communication/interaction with peers or others in their network. Hence, even though students' main intention in these sites is to socialise (Prichard 
2013), learning can still occur as a by-product of the socialisation. Kabilan et al. (2010, citing Lankard 1995) explained this as "incidental learning" where the main intention of carrying out an activity is to undertake a task and not to learn.

Along the same line, Prichard (2013, citing Mitchell 2009) commented that use of SNSs has provided language learners opportunities for communication practice, resulting in incidental learning for many language learners. In these social spaces, the focus of language use is more on meaning making and negotiation of meaning than on the form or structures of the language. Thus, the language is not the object to achieve but rather the medium through which other interpersonal goals are pursued (Abrams 2013). Kabilan et al. (2010, p. 184) borrowing from Wenger's (1998) understanding of learning suggested that students are somewhat successful in learning languages in SNSs because in these social sites "they are focused on the experience of meaning making rather than on the mechanics of language learning".

Social media in general can play an important role in the acquisition of the English language for ESL learners especially at the tertiary level. Language acquisition is defined by Shaul (2014) as being exposed to the language in a meaningful way so that learners acquire the structures of the language through actual use. This is contrasted to the idea of language learning where the focus is on teaching the language and its structures to the learners in the hope that they learn what is taught. The results presented by this study seem to support the notion that SNSs are best used as an acquisition tool rather than the classical teaching and learning tool. However, SNSs are a complicated landscape (Vivian, Barnes, Geer \& Wood 2014); it is therefore imperative for Malaysian universities to educate students on how to effectively embrace technologies like SNSs to support their learning and how to self-manage their learning within these social environments to gain benefit from their use, including for language learning. Additionally, language educators at the universities need to be cognizant of the affordances of these SNSs and find ways to maximize their benefits. This needs to be done with careful considerations of what constitute formal and informal language learning.

\section{CONCLUSION}

Malaysian university students reported making use of SNSs to improve their English. This should be taken as a good sign by English language instructors at the tertiary level. However, it is also useful to keep in mind that students use of technology for learning would most likely be personalised and tailored by them to meet their learning needs so that ultimately the appropriation of the technology would support their learning. Blanket use of technology without due considerations for factors like learning preferences should be avoided. This paper has also presented the areas in which SNSs could be useful as additional tools for language teachers, namely writing skills, communication skills, vocabulary development and reading skills. Although this is as perceived by the respondents, the patterns described in this paper are reflective of other studies that looked at SNS use and English language learning. Indeed, many of the other studies on SNSs and language learning have investigated how SNSs can be used in the English language classroom to support development of writing, reading, communication skills and vocabulary development (e.g. Kabilan et al. 2010; Yunus et al. 2012; Blattner \& Fiori 2009; Gamble \& Wilkins 2014). This somewhat suggests that the use of SNSs is facilitative in and suitable for developing these four areas of language proficiency, and instructors could stand to benefit by exploiting the potential of SNSs to support these areas of language learning. 


\section{REFERENCES}

Abrams, Zsuzsanna I. (2013). Computer-Mediated Communication and Second Language Use. In Chapelle, Carol A. (ed.). The Encyclopedia of Applied Linguistics, 1-6. Blackwell Publishing Ltd.

AbuSa'aleek, A. O. (2015). Students' perceptions of English language learning in the Facebook context. Teaching English with Technology. 15(4), 60-75. Retrieved August 30 ${ }^{\text {th, }} 2019$ from https://eric.ed.gov/?id=EJ1138432.

Alm, A. (2015). Facebook for informal language learning: Perspectives from tertiary language students. The EUROCALL Review. 23(2), 3-18.

Ary, D., Jacobs, C.J., Razavieh, A. \& Sorenson C.K. (2009). Introduction to research in education. 8th Ed. United Kingdom: Wadsworth Publishing.

Aydin, S. (2012). A review of research on Facebook as an educational environment. Education Technology Research and Development. 60(6), 1093-1106.

Balakrishnan, V., Teoh, K. K., Pourshafie, T. \& Liew, T. K. (2017). Social media and their use in learning: A comparative analysis between Australia and Malaysia from the learners' perspectives. Australasian Journal of Educational Technology. 33(1), 81-97.

Blattner, G. \& Fiori, M. (2009). Facebook in the language classroom: Promises and possibilities. International Journal of Instructional Technology \& Distance Learning. 6(1), 17-28.

Borg, S. (2003). Teacher cognition in language teaching: a review of research on what language teachers think, know, believe, and do. Language Teaching. 36, 81-109.

Bosch, T. (2009). Using online social networking for teaching and learning: Facebook use at the University of Cape Town. COMMUNICATIO. 35(2), 185-200.

Chen, B. \& Bryer, T. (2012). Investigating Instructional Strategies for Using Social Media in Formal and Informal Learning. The International Review of Research for Open and Distance Learning. 13(1), 87-104.

Dabbagh, N. \& Kitsantas, A. (2012). Personal Learning Environments, Social Media, and Self-Regulated Learning: A Natural Formula for Connecting Formal and Informal Learning. Internet and Higher Education. 15(1), 38.

Dalsgaard, C. (2006). Social Software: E-learning beyond learning management systems. European Journal of Open, Distance and E-Learning, 2006/II.

Dogoriti, E. \& Pange, J. (2013). Considerations for online English Language Learning. The use of facebook in Formal and Informal Settings in Higher Education. In Gorg Mallia (ed.). The Social Classroom: Integrating Social Network Use in Education. (pp.147-171) IGI Global.

Ekoc, A. (2014). Facebook Groups as a Supporting Tool for Language Classrooms. Turkish Online Journal of Distance Education. 15(3), 18-26.

Ellison, N.B., Steinfeld, C., and Lampe, C. (2007). The benefits of Facebook "Friends": Social capital and college students' use of online social network sites. Journal of Computer Mediated Communication. 12(4), 11431168 .

Ellison, N. (2008). Introduction to social network sites. In Salaway, G. and Caruso, J. B. (with M. R. Nelson) The ECAR Study of Undergraduate Students and Information Technology, 2008. ECAR Research 17 Study 8. Boulder, CO: EDUCAUSE Center for Applied Research, 2008.

Espinosa, L.F. (2015). The Use of Facebook for Educational Purposes in EFL Classrooms. Theory and Practice in Language Studies. 5(11), 2206-2211.

Gamble, C. \& Wilkins, M. (2014). Student Attitudes and Perceptions of Using Facebook for Language Learning. The 2013 WEI International Academic Conference Proceedings. Orlando, USA. Retrieved September $1^{\text {st }}$, 2019 from https://files.eric.ed.gov/fulltext/EJ1080264.pdf.

Gao, F., Luo, T. \& Zhang, K. (2012), Tweeting for learning. British Journal of Educational Technology. 43, 783801. doi:10.1111/j.1467-8535.2012.01357.x

Gharehbagh, M. J., Stapa, S. H. \& Darus, S. (2019). The effects of written corrective feedback using wikis among ESL learners. 3L: Language, Linguistics, Literature. 25(1), 1-10. https://doi.org/10.17576/3L-2019-250104

Godwin-Jones, R. (2006). Tag clouds in the blogosphere: Electronic literacy and social networking. Language Learning \& Technology. 10(2), 8-15.

Greenhow, C. \& Robelia, B. (2009). Old Communication, New Literacies: Social Network Sites as Social Learning Resources. Journal of Computer Mediated Communication. 14(4),1130-1161. 
Gunawardena, C.N., Hermans, M.B., Sanchez, D., Richmond, C., Bohley, M. \& Tuttle, R. A. (2009). Theoretical framework for building online communities of practice with social networking tools. Educational Media International. 46(1), 3-16A.

Hew, K. F. (2011). Students' and teachers' use of Facebook. Computers in Human Behavior, 27(2), 662- 678.

Hewitt, A. \& Forte, A. (2006). Crossing boundaries: Identity management and student/faculty relationships on the Facebook. Presented at the Computer Supported Cooperative Work Conference, Banff, Alberta, Canada. Retrieved September $\quad 2^{\text {nd }}, \quad 2019 \quad$ from https://www.researchgate.net/publication/238079412_Crossing_Boundaries_Identity_Management_and_St udentFaculty_Relationships_on_the_Facebook.

Kabilan, M.K., Ahmad, N., \& Zainol Abidin, M.J. (2010). Facebook: An online environment for learning of English in institutions of higher education? The Internet and Higher Education 13 (4), 179-187.

Kasuma, S.A.A. (2017). Using Facebook For English Language Learning: The Differences Among Gender and Ethnicity. Journal of Nusantara Studies 2017, 2(1), 177-193.

Kiser, A. \& Porter, T. (2011). Social Networking: Integrating Student and University Professor Utilization. Global Conference on Business and Finance Proceedings, Vol. 6 (2), 191-196. The Institute of Business and Finance Research, San Jose, Costa Rica. May 24-27, 2011.

Knight, J. \& Rochon R. (2012). Starting Online: Exploring the use of a Social Networking Site to Facilitate Transition into Higher Education. The Electronic Journal of e-Learning, 10 (3), 259-261. Retrieved September $2^{\text {nd }}, 2019$ from www.ejel.org/issue/download.html?idArticle $=225$.

Lampe, C., Ellison, N., \& Steinfield, C. (2008). Changes in Use and Perception of Facebook. In Proceedings of the 2008 Conference on Computer-Supported Cooperative Work (CSCW 2008), (pp. 721-730). San Diego, CA, USA

Lamy, M.N. \& Zourou, K. (2013). Social networking for language education. Basingstoke, UK: Palgrave Macmillan.

Lay Shi, N., Thang, S. M., \& Mohd Noor, N. (2018). The usage of social networking sites for informal learning: A comparative study between Malaysia students of different gender and age group. International Journal of $\begin{array}{llll}\text { Computer-Assisted Language Learning and Teaching, 8(4), } & \text { 76-88. }\end{array}$ https://doi.org/10.4018/IJCALLT.2018100106

Lomicka, L., \& Lord, G. (2016). Social networking and language learning. In F. Farr \& L. Murray (Eds.), The Routledge Handbook of Language Learning and Technology. (pp. 255-268). New York: Routledge.

Looi, C. Y. and Farrah Dina Yusop. (2011). Potential use of social networking tool to assist reading comprehension: Implications for practice and future research. Jurnal Pendidikan 31(1),189-201.

Madge, C., Meek, J., Wellens, J. \& Hooley, T. (2009). Facebook, social integration and informal learning at university: It is more for socialising and talking to friends about work than for actually doing work. Learning, Media and Technology, 34(2), $141-155$.

Mahmud, M. M., \& Ching, W. S. (2012). Facebook does it really work for L2 learners. Academic Research 3 (2), 357-370.

Manca, S., \& Ranieri, M. (2016). Facebook and the others: Potentials and obstacles of social media for teaching in higher education. Computers \& Education 95 (C), 216-230.

Manca, S., \& Ranieri, M. (2013). Is it a tool suitable for learning? A critical review of the literature on Facebook as a technology-enhanced learning environment. Journal of Computer Assisted Learning 29(6), 487-504.

Mazer, J., Murphy, R. \& Simonds, C. (2007). I'll see you on 'Facebook': The effects of computer-mediated teacher self-disclosure on student motivation, affective learning, and classroom climate. Communication Education 56(1), 1-17.

Mazman, S.G. \& Usluel, Y.K. (2010). Modelling educational usage of Facebook. Computers \& Education 55 (2), 444-453.

McBride, K. (2009). Social networking sites in foreigh language classes: Opportunities for re-creation. In Lomicka, L. \& Lord, G. (eds.). The next generation: Social networking and online collaboration in foreign language learning (pp. 35-58). San Marcos, TX: CALICO Press.

McLoughlin, C. \& Lee, M. (2008). Future Learning Landscapes: Transforming Pedagogy through Social Software. Innovate 4(5). Retrieved August 30 ${ }^{\text {th }}, 2019$ from http://fr.slideshare.net/umiami/innovate-future-learninglandscapes-transforming-pedagogy-through-social-software.

Omar, A., Amir, Z., \& Mohamad, M. (2018). Facilitating online learning: Students' online discussion strategies for a project work at a technical university in Malaysia. 3L: Language, Linguistics, Literature, 24(4), 102-114. https://doi.org/10.17576/3L-2018-2404-08 
Ophus, J. D. \& Abbitt, J. T. (2009). Exploring the potential perceptions of social networking systems in university courses. MERLOT Journal of Online Learning and Teaching 5(4), 639-648.

Prichard, C. (2013). Using social networking sites as a platform for second language instruction. TESOL Journal 4 (4), $752-758$.

Roblyer, M.D., McDaniel, M., Webb, M., Herman, J., \& Witty, J.C. (2010). Findings on Facebook in higher education: A comparison of college faculty and student uses and perceptions of social networking sites. The Internet and Higher Education 13 (3), 134-140.

Rodríguez-Hoyos, C., Haya, I., \& Fernández-Díaz, E. (2015). Research on SNS and education: the state of the art and its challenges. Australasian Journal of Educational Technology, 31(1), 100-111.

Romero-Frías, E., \& Arquero, J. L. (2013) A view on personal learning environments through approaches to learning. Journal for Innovation and Quality in Learning (INNOQUAL) 1(1), 29-36.

Salaway, G., Caruso, J.B. \& Nelson M. R. (2008). The ECAR study of undergraduate students and information technology, 2008. ECAR Research 17 Study 8. Boulder, CO: EDUCAUSE Center for Applied Research.

Saykili, A., \& Kumtepe E.G. (2014). Facebook's hidden potential: Facebook as an educational support tool in Foreign Language Learning. In Mallia, G. (Ed.), The social classroom: Integrating social network use in education (pp. 120-207). Hershey, PA: IGI Global. doi:10.4018/978-1-4666-4904-0

Selwyn, N. (2009). Faceworking: exploring students' education-related use of Facebook. Learning, Media and Technology, 34(2), 157-174.

Selwyn, Neil. (2007). Screw Blackboard ... do it on Facebook!': An investigation of students' educational use of Facebook. Poke 1.0: Facebook social research symposium. London, 15 November 2007.

Shaul D.L. (2014) Language Acquisition vs. Language Learning. In: Linguistic Ideologies of Native American Language Revitalization. Springer. Briefs in Anthropology. Springer, Cham. https://doi.org/10.1007/978-3319-05293-9_3

Shaw, Carolyn M. (2015). Using Facebook as an Educational Resource in the Classroom. Oxford Research Encyclopedia of International Studies. USA: Oxford Univeristy Press.

Smith, S.D., Salaway, G., \& Caruso, J.B. (2010). The ECAR study of undergraduate students and information technology. ECAR Research Volume 6. Boulder, CO: EDUCAUSE Center for Applied Research.

Subrahmanyam, K. Reich, S.M., Waechter, N. \& Espinoza, G. (2008). Online and offline social networks: Use of social networking sites by emerging adults. Journal of Applied Developmental Psychology (29), 420-433.

Suthiwartnarueput, T. \& Wasanasomsithi, P. (2012). Effects of Using Facebook as a Medium for Discussions of English Grammar and Writing of Low-Intermediate EFL Students. Electronic Journal of Foreign Language Teaching. 9(2), 194-214. Retrieved September $1^{\text {st }}, 2019$ from http://eflt.nus.edu.sg/v9n22012/suthiwartnarueput.pdf.

Tan, E.X. \& Low, Y.C. (2010). The Perception and Acceptance of Students towards using Social Networking Sites in Teaching and Learning. In Z. Abas, I. Jung \& J. Luca (Eds.), Proceedings of Global Learn Asia Pacific 2010--Global Conference on Learning and Technology (pp. 247-252). Penang, Malaysia: Association for the Advancement of Computing in Education (AACE).

Tess, P. A. (2013). The role of social media in higher education classes (real and virtual)-A literature review. Computers in Human Behavior. 29(5), A60-A68.

Towner, T.L. \& Munoz, C.L. (2011). Facebook and Education: A Classroom Connection. Educating Educators with Social Media. Cutting Edge Technologies in Higher Education. 1, 33 - 57.

Trinder, R. (2017). Informal and deliberate learning with technologies. ELT Journal. 71(4), 401-412.

Vivian, R. (2011). University Students' Informal Learning Practices Using Facebook: Help or Hindrance? Enhancing Learning Through Technology. Education Unplugged: Mobile Technologies and Web 2.0 Communications. Computer and Information Science. 177, 254-267.

Vivian, R., Barnes, A., Geer, R. \& Wood, D. (2014). The academic journey of university students on Facebook: an analysis of informal academic-related activity over a semester. Research in Learning Technology. 22(1), 116.

Warschauer, M. (2009). 'Foreword'. In Thomas, M. (ed.). Handbook of research on Web 2.0 and second language learning (pp. xix-xx). IGI Global.

Wenger, E. (1998). Communities of practice: learning, meaning, and identity. Cambridge University Press, 1998.

Woo, Y., Herrington, J., Agostinho, S. \& Reeves, T. C. (2007). Implementing authentic tasks in web-based learning environments. Educause Quarterly. 30(3), 36-43.

Yang, Y., Wang, Q., Woo ,H. L. \& Quek, C. L. (2011). Using Facebook for teaching and learning: A review of the literature. International Journal of Continuing Engineering Education and Life-Long Learning. 21(1), $72-$ 86. 
Yunus, M.M. \& Salehi, H. (2012). The effectiveness of Facebook groups on Teaching and Improving Writing: Students' perceptions. Journal of Education and Information Technologies. 1(6), 87-96.

Yunus, M.M., Salehi, H. \& Chen, C. (2012). Integrating social networking tools into ESL writing classroom: Strengths and weaknesses. English Language Teaching. 5(8), 42-48.

Zourou, K. (2012). On the attractiveness of social media for language learning: A look at the state of the art. Alsic. $15(1)$. 